
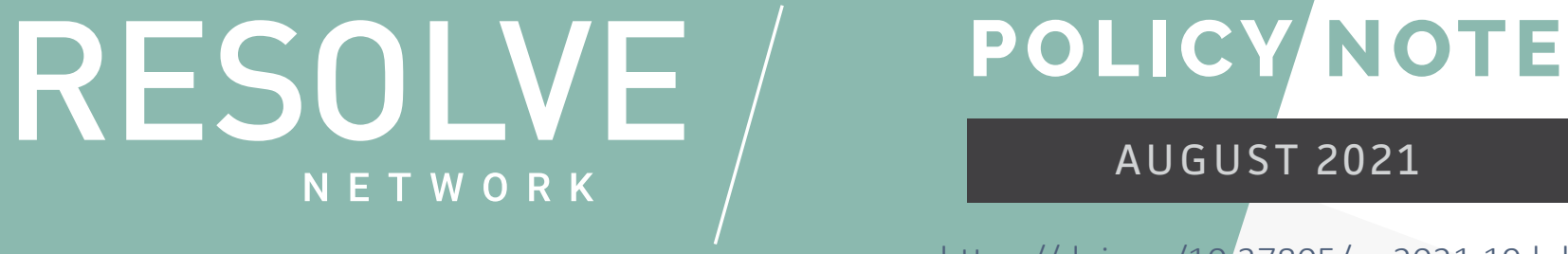

https://doi.org/10.37805/pn2021.19.Ipbi

\title{
BUILDING PEACE THROUGH DDR PROGRAMS: LESSONS FROM REINTEGRATING BOKO HARAM EX-RECRUITS IN CAMEROON
}

\author{
LYDIE C. BELPORO
}

LEARNING FROM LOCAL

PEACEBUILDING APPROACHES

\section{"The governance of exits from extremist violence and implementation of DDR processes in Cameroon must be better adapted to local realities."}

\section{FAST FACTS}

$\rightarrow$ Cameroon's choice to focus its DDR programming primarily on deradicalization is particularly

unsuitable.

$\rightarrow$ Cameroonian authorities should rely on the experience, knowledge, and research amassed during the past 30 years to avoid creating new grievances.

$\rightarrow$ Formal engagement with complementary indigenous and religious practices and administrative processes could improve reintegration efforts.

$\rightarrow$ The reintegration process of Boko Haram ex-associates should be based on community support.
Context

In the countries of the Lake Chad Basin, Boko Haram's emergence has created major new security challenges for the region's governments. With a population of nearly 3,993,007 inhabitants spread over 34,263 km, Cameroon's Far North region, the most populous in the country, is at the heart of these security issues. ${ }^{1}$ Since late 2020, Boko Haram has intensified attacks in Far North localities with assassinations targeting civilians, kidnappings, and looting in small towns along the Nigerian border. These incursions have displaced nearly 300,000 people and killed more than 5,000 since the crisis began. ${ }^{2}$

1 National Institute of Statistics, "Annuaire Statistique de La Région de I'Extrême Nord," 2019 Edition, https://ins-cameroun.cm/statistique/ annuaire-statistique-de-la-region-de-lextreme-nord-edition-2019/.

2 According to the Norwegian Refugee Council in 2020, Cameroon has been ranked as the first of the world's most neglected displacement crises. NRC, "The world's most neglected displacement crises in 2019," June 10, 2020, https://www.nrc.no/shorthand/fr/theworlds-most-neglected-displacement-crises-in-2019/index.html. 
In response, the Cameroonian government has pursued a hardline strategy and militarized the affected localities. At the regional level, the cooperation and diplomatic strategy was consolidated with the creation of a Multinational Joint Task Force (MNJTF) in 2015 between Cameroon, Nigeria, Benin, Chad, and Niger. The MNJTF's main mission is to secure the states by dealing with and coordinating interventions in common cross-border security issues. At the national level, Cameroon's anti-terrorism law 2014/028 of December 23, 2014 3 provides the death penalty for citizens who, either as individuals or in a group, carry out, abet, or sponsor terrorism. According to a recent Cameroonian Ministry of Justice report, in 2018 nearly 217 individuals were prosecuted at the Maroua Military Court under this law; the report also recorded 87 proceedings and 45 acquitted individuals. ${ }^{4}$

Cameroon's legal response to terrorism has raised concerns among civil society groups inside the country and internationally. ${ }^{5}$ In addition to arbitrary arrests, prolonged pre-trial detention, prison overcrowding, and the death penalty are all sources of concern. The 2014 anti-terrorism bill's ambiguity and lack of clarity has contributed to the proliferation of harsh sentences and a general shift from a legal "state of law" to a "state of police."

While waiting for the amendment or repeal of this controversial law, a presidential decree created a National Committee for Disarmament, Demobilization, and Reintegration (CNDDR) on November 30, 2018. ${ }^{7}$ This committee is responsible for the care of Boko Haram ex-fighters and armed groups operating in the English-speaking regions of the country in the midst of a violent conflict since late 2016. This responsibility includes reintegrating former fighters or associates of Boko Haram who have defected in recent years. ${ }^{8}$

3 Law No. 2014/028 of 23 December 2014 on the Suppression of Acts of Terrorism in Cameroon, 2014, http://www.assnat.cm/ gestionLoisLegislatures/libraries/files upload/uploads/Lois/2014-028fr.pdf.

4 Ministry of Justice Cameroon, "Report of the Ministry of Justice on the State of Human Rights in Cameroon in 2017 and Compilation of International, Regional and National Human Rights Instruments," February 2019, 237, https://www. spm.gov.cm/site/?q=fr/content/rapport-du-minist\%C3\%A8re-de-la-justice-sur-1\%E2\%80\%99\%C3\%A9tat-des-droits-de1\%E2\%80\%99homme-au-cameroun-en-2017.

5 Jean-Claude N. Ashukem, "To Give a Dog a Bad Name to Kill It - Cameroon's Anti-Terrorism Law as a Strategic Framework for Human Rights' Violations," Journal of Contemporary African Studies 39, no. 1 (January 2, 2021): 119-34, https://doi.org/10.1 080/02589001.2020.1839633.

6 The Military Tribunal is an exceptional jurisdiction with special competence, giving it absolute jurisdiction over acts of terrorism in Cameroon. See: Stève Thiery Bilounga, "L'Etat camerounais à la croisée des chemins de l'Etat de droit et de l'Etat de police (A propos de la loi du 23 décembre 2014 portant répression des actes de terrorisme)," Droit en Afrique 19, no. 2 (2016): 139-161.

7 Presidency of the Republic of Cameroon, "Decree No. 2018/719 on the creation of the National Committee for Disarmament, Demobilization and Reintegration," November 30, 2018, https://www.prc.cm/en/news/the-acts/decrees/3177-decree-n2018-719-of-30-november-2018-to-establish-the-national-disarmament-demobilization-and-reintegration-committee.

8 The term "association" has a broader coverage and is used to refer to "all persons (regardless of age, relationship, gender, etc.) with whom authorities believe have had contact with Boko Haram or [the Islamic State in West Africa] EIIL without presuming or prejudging the nature of their relationship with Boko Haram or ElIL." It also refers to women and children who may be victims of Boko Haram. This latter, broader definition is the definition of "ex-associates" used in this policy note. In the context of DDR, an associate is someone including family members who is not in a leadership position and who supports extremist group. See: African Union (AU), Lac Chad Basin Commission (LCBC), "Annexe 3 Document relatif aux piliers de la CBLT et de la CUA triage, poursuites, réhabilitation et réintegration," 2018, 7, https://www.peaceau.org/uploads/ annexe-3-document-relatif-pour-le-triage-poursuites-rehabilitation-et-reintegration.pdf. 
This policy note outlines core findings from a case study of the Boko Haram ex-associates reintegration process in Cameroon. Drawing upon field research and observations conducted late 2020 in Maroua, Mora, Méri, and Yaoundé, grey literature and documentaries sources, ${ }^{9}$ this note examines how existing community norms or mechanisms might be as useful as more standard approaches to disarmament, demobilization, and reintegration ${ }^{10}$ (DDR) in addressing challenges presented by Boko Haram ex-associates in Cameroon.

\section{Relevance to Policy and Practice}

The scholarly literature on peacebuilding has assessed exits from institutional violence along with other approaches rooted in conflict resolution. But research focusing on exits from radical and violent extremist groups is rather rare and mostly seeks to understand "push," "pull," and risk factors in explaining disengagement. ${ }^{11}$ Considering the numerous failures of DDR program implementation in African countries, ${ }^{12}$ this policy brief highlights to policymakers and practitioners the need to develop a hybrid model between traditional/local and institutional/formal approaches that closely involve multiple stakeholders.

The management of individuals accused of having been associated with jihadist groups in Cameroon also raises a new set of critical questions regarding the role of local communities in peacebuilding. Countering violent extremism (CVE) programs must consider the multiple overlapping needs of those who are at the exit of their extremist journeys, with a particular emphasis on local realities and how they can be addressed through local initiatives. This policy note outlines four lessons learned regarding peacebuilding initiatives and DDR program ${ }^{13}$ opportunities and challenges, informed by criminological and sociology of public policy scholarship on participation in political violence.

9 The one-on-one interviews involved discussions with ex-recruits, public and traditional stakeholders, youth leaders, academics, civil society actors, and international organizations in Cameroon.

10 In the context of association with Boko Haram, disarmament is individual and it occurs when the military or the MMF capture or accept the surrender of individuals; demobilization is more of a detention phase including a rehabilitation process or prosecution for some, which will pave the way for reintegration or return to the community. See: AU/LCBC, 11.

11 Mary Beth Altier, Emma Leonard Boyle, Neil D. Shortland, and John G. Horgan, "Why They Leave: An Analysis of Terrorist Disengagement Events from Eighty-seven Autobiographical Accounts," Security Studies 26 no. 2 (2017): 305-332, https://doi. org/10.1080/09636412.2017.1280307; Sarah Mardsen, Reintegrating Extremists: Deradicalisation and Desistance (London: Palgrave Macmillan, 2016); Martine Herzog-Evans and Massil Benbouriche, Evidence-based work with violent extremists: International implications of French terrorist attacks and responses (Lanham, MD: Lexington Books, 2019).

12 Jocelyn Coulon and Damien Larramendy, Consolidation de la paix et fragilité étatique : I'ONU en République centrafricaine (Montréal : Les Presses de l'Université de Montréal, 2015).

13 Cameroon's DDR program approach is part of a third generation DDR approach where the level of conflict is unfinished. It is based in part on the commitments made in the Lake Chad Basin Commission's regional strategy for Boko Haram-affected areas adopted in Abuja on August 30, 2018. It also relies on national DDR Frameworks operational guidelines of the African Union Commission stated in 2014, which are compliant with the United Nations Integrated Disarmament, Demobilization and Reintegration Standards (IDDRS), and on the regional strategy promoted by the Lake Chad Basin Commission (LCBC) and the African Union Commission (AUC) for the stabilization, recovery, and resilience of areas affected by Boko Haram or the Islamic State in West Africa (EIIL). African Union, Lake Chad Basin Commission, Regional strategy for the stabilization, recovery \& resilience of the Boko Haram affected areas of the Lake Chad Basin region, 2018, https://www.peaceau.org/uploads/regional-stabilisation-recovery-and-resilience-strategy-rss-.pdf; African Union Commission, African Union Disarmament, Demobilisation and Reintegration Capacity Program, 2014, https://www.peaceau.org/uploads/au-operational-guidance-note-on-nationalframeworks.pdf. 


\section{Recommendations}

\section{Create policy for exiting violence and transplant programs tailored for the local context in Cameroon}

Cameroon's choice to focus its DDR programming primarily on deradicalization is particularly unsuitable, unlike in Nigeria where religion was a frequent tool for recruitment into Boko Haram. ${ }^{14}$ The Cameroonian government, via CNDDR which is responsible to "take the necessary steps de-radicalize ex-fighters," 15 has opted for Boko Haram ex-associates to go through two phases before their reintegration, beginning with de-radicalization considered as "reverse brainwashing," and ending with socialization, understood as "reintegration of de-radicalized people into their communities of origin." 16

Yet this design is inconsistent with what is known about how Cameroonian ex-fighters became affiliates of the group. If ideological and religious factors were the drivers for the first followers who came into contact with Boko Haram and joined in 2009, ${ }^{17}$ since 2014 socio-cultural factors, governance and economic marginalization have emerged as the main drivers of political and economic radicalization in Cameroon. Poverty is also a huge factor of engagement with Boko Haram, which often took advantage of local crime to recruit followers or used intimidation and kidnappings to strengthen its ranks. ${ }^{18}$ Boko Haram was also able to take advantage of some local criminal actors who were already operating in organized crime at the time and converted their criminal experiences to serve the extremist group. The Far North region was facing challenges related to banditry through the "highway robbers' phenomenon." 19 As also shown by a 2017 UNDP study on journeys to extremism in Africa, considering the low level of religious knowledge of recruits, Boko Haram is using a manipulative and opportunistic interpretation of religion to attract individuals. ${ }^{20}$

Since in Cameroon, for the time being, most of the DDR activities being carried out in the Far North focus on training for income-generating activities and civic and moral education, it would be more useful to conceptualize that disengagement and training programming as community re-integration of ex-associates rather than deradicalization. This recommendation requires an amendment of article 2 under paragraph 3 of the Decree on reintegration, which speaks to

14 Atta Barkindo and Shane Bryans, "De-Radicalising Prisoners in Nigeria: developing a basic prison based de-radicalisation programme," Journal for Deradicalization 7 (2016): 1-25, https://journals.sfu.ca/id/index.php/jd/article/view/56/47.

15 On reintegration Decree article 2 under paragraph 3.

16 Bana Barka, “Déradicaliser au nom de Dieu ?” L’CEil du Sahel, 1038 (19 février, 2018): 2.

17 Saibou Issa, "Étude des stratégies de prévention et de lutte contre l'extrémisme violent ciblant les jeunes et les femmes dans I'Extrême-Nord (Cameroun)," (Mai 2019), UNFPA.

18 Christian Pout, Bana Barka, and Edouard Yogo, Boko Haram Au Cameroun : Quelles Nouvelles Dynamiques? (Paris: Du Cygne, 2019).

19 Considered as armed bandits who are used to attacking and holding road users for ransom and taking hostages. Saïbou Issa, Les " coupeurs de route ». Histoire du banditisme rural et transfrontalier dans le bassin du lac Tchad (Paris: Karthala, 2010); International Crisis Group, "Cameroun : faire face à Boko Haram," 2016, 241, https://www.crisisgroup.org/fr/africa/ central-africa/cameroon/cameroon-confronting-boko-haram.

20 "Journey to extremism in Africa," UNDP Regional Bureau for Africa, accessed June 13, 2021, https://digitallibrary.un.org/ record/3841751. 
deradicalization for Boko Haram ex-associates in the Far North. ${ }^{21}$ Therefore, the labelling of the program and its ambitions should be focusing on physical estrangement from violence and speak about providing economic and social insertion opportunities to Boko Haram ex-associates.

\section{Prevent the risks of recidivism and reverting to violence by a definite schedule for reintegration}

At first, caught off guard by the large wave of returning ex-fighters in villages, Cameroonian authorities initially temporarily referred returning individuals to humanitarian organizations then the MNJTF before taking steps to welcome them into their own DDR programs. These individuals and some of their dependents are now being cared for in the old Meri prison while waiting for the new facility at Mémé to open. Yet, it has been more than three years since the first batch of returnees moved from the MNJTF to Meri. In May 2021, there were approximately 335 people in care at the Méri transit camp in the Diamaré department. ${ }^{22}$ The reception area is very narrow, no date has been set for the end of their stay in the closed environment, and there is no clear plan for their reintegration into communities. The modalities of reintegration into the community are also unclear.

Cameroonian authorities should rely on the considerable experience and knowledge amassed during the past 30 years and glean from the robust body of research to avoid creating new grievances by forcing returnees to cope with a with long period of uncertainty about the future. As noted in a recent RESOLVE Network research report on DDR, "holding individuals for lengthy periods and/or in inhumane conditions leads to a discourse of resistance against the state or external actors that impedes reintegration." ${ }^{23}$ One factor that can undermine the Cameroonian DDR process is the failure to set a timeline and adequate resources.

Moreover, since Boko Haram is still conducting some attacks, to encourage more defections, this should be a fluid dynamic to avoid recreating frustrations or vulnerabilities that lead individuals back to violence. Therefore, Cameroon's DDR should follow the United Nations Integrated Disarmament, Demobilization and Reintegration Standards (IDDRS) revised in 2019,24 which provided that for those leaving groups designated as terrorist organizations the exit strategy should be well-planned and last for a specific period of time.

Organizing care for individuals who have been associated with extremism should not be planned haphazardly or extemporaneously. An official timetable providing a clear and detailed plan for

21 This is especially true since the rationality of the conflict and needs for the care of Boko Haram ex-fighters are very different from those of the insurgents who were involved in the Anglophone crisis in Cameroon. The same National Committee is responsible of the DDR of former Anglophone separatists engaged in the armed conflict against government forces for secession of the country's English-speaking North-West and South-West regions since 2016. See: René Ngek Montehk, "Disarmament, Demobilization and Reintegration (DDR). A New Paradigm in the Resolution of the Ongoing Anglophone Crisis in Cameroon: Myth or Reality," International Journal of Research and Innovation in Social Science, no. V (2021): 390-400.

22 Figures communicated on May 2, 2021, by the responsible DDR center for the far North. Cameroon Tribune, May 2021, https://camerounactuel.com/desarmement-demobilisation-et-reintegration-les-missions-expliquees-a-mora/.

23 Mary Beth Altier, Violent Extremist Disengagement \& Reintegration: Lessons from Over 30 Years of DDR, (Washington, D.C.: RESOLVE Network, 2021): 2, https://doi.org/10.37805/vedr2021.1.

24 Demobilization Interagency Working Group on Disarmament, and Reintegration, "Module 2.10: The UN Approach to DDR," Integrated DDR Standards, 2019, 29, https://www.unddr.org/modules/IDDRS-2.10-The-UN\%20Approach-to-DDR.pdf. 
moving through stages towards the transition to return to the community should be a priority objective for the Cameroonian authorities. So should be a plan for the monitoring and evaluation of DDR programs.

\section{Formalize and institutionalize traditional reintegration processes with local stakeholders in support of DDR}

The AU commission's National DDR Frameworks Operational Guidelines state that DDR and justice programs should "utilize indigenous and informal traditions for administrating justice or settling disputes" and "consult with victims' groups and communities receiving" ex-associates. ${ }^{25}$ Before the official DDR process was set up in Cameroon, initial peaceful steps had been taken in localities in the Far North through the creation of sessions during which the ex-insurgents were invited to renounce and abandon Boko Haram. These public demarches were an opportunity for the former members of the group to show their good faith by swearing on the Koran in front of the traditional authorities that they would abandon all collaboration with Boko Haram. ${ }^{26}$ Traditional soft power diplomacy can play a pivotal role in the reintegration and management of former Boko Haram associates since symbolic power of local authorities is great in the northern regions. Cameroon is formed on a pluralist system in which traditional leaders play roles in the organization of civil lifeit is imperative to involve them in these processes. ${ }^{27}$ Institutionalizing and formalizing traditional practices, that are better suited than DDR programs only in this context, allows the participation of the whole community including traditional leaders and families.

If officially supervised by the state, these processes would give legitimacy to the weight and value of local initiatives and have better results. In Cameroon, the DDR program was created in a topdown manner (i.e. the National DDR Commission brings together representatives of the main ministries by the most senior government official). However, for reintegration to succeed, it must be done in a bottom-up manner that integrates local and traditional stakeholders. Echoing the recent ISS Report on exiting from violence in Lake Chad, ${ }^{28}$ the critical focus of DDR policy should be on engaging all the community's layers in leadership structures.

Since in Cameroon the process of screening returnees is done upstream with the defense security force, the judicial police, the army, the gendarmerie, the police, the traditional authorities (village chiefs, lawan and lamido) and local administrative authorities (the mayor, prefect, sub-prefect), all these stakeholders must also be involved at every step of the reintegration process. Local vigilance committees, for example, have worked with the government to manage the security threat posed

25 African Union Commission, "National DDR Frameworks Operational Guideline," African Union Disarmament, Demobilisation and Reintegration Capacity Program, 2014, 29.

26 Issa Saïbou and Nadine Machikou, "Reintegrating Former Boko Haram Associates. Perspectives from the Far North," Global Center on Cooperative Security, February 2019, https://www.globalcenter.org/publications/ reintegrating-former-boko-haram-associates-reintegration-des-ex-associes-de-boko-haram/.

27 Charles Mback Nach, "La Chefferie traditionnelle au Cameroun: ambiguïtés Juridiques et dérives politiques," Africa Development / Afrique et Développement 25, no. 3/4 (2000): 77-118.

28 Akum Fonteh, Hoinathy Remadji, and Samuel Malik, "Managing the Journey out of Violent Extremism in the Lake Chad Basin," ISS Africa, March 30, 2021, 15, https://issafrica.org/research/west-africa-report/ managing-the-journey-out-of-violent-extremism-in-the-lake-chad-basin. 
by Boko Haram. These popular grassroots self-defense units have been re-established in the fight against Boko Haram. Their engagement could be helpful in the reintegration process. ${ }^{29}$

Similarly, formal engagement with complementary indigenous and religious practices and administrative processes could improve reintegration efforts. This can be done through intercommunity dialogue and capacity building of traditional and religious stakeholders. Some initiatives have implemented spaces for intergenerational dialogue on peace, for example by the UNFPA-coordinated "Youth and Stabilization for Peace and Security in the Far North Region of Cameroon." ${ }^{30}$ However, current efforts are limited and do not meet all of the needs, which remain high in Logone and Chari, Mayo Sava, and Mayo Tsanaga.

A key question in the arrondissements or village headquarters is who can help translate the presidential decree on DDR and reintegration into local languages. Interviewees report that the decree remains little known and understood by most of the local population who still have distrust for people associated with Boko Haram. ${ }^{31}$ Efforts should be made to improve the information flow for awareness-raising and community sensitization and to adapt all projects to cultural and social norms. These messages, which can be conveyed both online and via local radio, should strengthen social cohesion and build community resilience, along with reducing ethnic discrimination against Kanuris, who are often profiled as Boko Haram members. ${ }^{32}$

\section{Plan macro, long-term, and intersectional interventions to strengthen community resilience}

The reintegration process of Boko Haram ex-associates should be based on community support. Both ex-combatants and communities should be provided with resources so as not to cultivate the feeling that the ex-associates are more favored than the victims. A 2017 report by the Cameroonian Ministry of Justice already stated that "the return to the community of some has posed the problem of social resilience" by local communities where many victims and survivors are still struggling. ${ }^{33}$ Therefore, Cameroonian authorities should work more closely with international stakeholders already in the field to coordinate projects and improve the living conditions of the surrounding affected populations. The security crisis has seriously affected agricultural activities and those that generate income in the region. The market for the fight against extremism has

29 They were established by Law 68/LF/1 of June 11, 1968. Placed under the authority of sub-prefects and traditional chiefs, they also play the role of barrages or protection militias. In 2014, there were more than 14,000 members employed by the vigilance committees in Cameroon's Far North. See: International Crisis Group, "Cameroun : faire face à Boko Haram," 2016, 241, https://www.crisisgroup.org/fr/africa/central-africa/cameroon/cameroon-confronting-boko-haram.

30 This UNFPA project has led to the creation of a community mediation platform for creating multifunctional centers and coaching youth ambassadors of peace. It is done in partnership with other agencies of the United Nations System and has received funding from the European Union in 2020.

31 This aligns with the report of the NGO Rayons de Soleil following a workshop on the integration process of Boko Haram exassociates in 2019 with the Departmental Youth Councils of the Far North for young people from the region.

32 See: Alawadi Zelao, "Boko Haram, identités et déconstruction des frontières nationales en Afrique sahélienne," Revue Béninoise de Science Politique (2017).

33 Ministry of Justice Cameroon, "Report of the Ministry of Justice on the State of Human Rights in Cameroon in 2017 and Compilation of International, Regional and National Human Rights Instruments," October 2018, 237, https://www. spm.gov.cm/site/?q=fr/content/rapport-du-minist\%C3\%A8re-de-la-justice-sur-1\%E2\%80\%99\%C3\%A9tat-des-droits-de\%E2\%80\%99homme-au-cameroun-en-2017. 
also resulted in the Far North region in an increasing presence of international institutions and a "tertiarization of activities" causing dependence on external aid. ${ }^{34}$

To allow populations to develop their resilience, it is vital to combine local initiatives and projects with national programs. In order not to hamper the resilience of the populations, beyond the provision of essential resources, it is imperative for them be able to return to their original cultures, lifestyles, and economic practices with the resumption of commercial activities in the region.

\section{Conclusion}

The governance of exits from extremist violence and implementation of DDR processes in Cameroon must be better adapted to local realities. This policy note has highlighted the importance of avoiding an agenda of end-of-violence programs oriented by top actors with the consequence of being disconnected from reality and thus being less effective. The need to adequately label the mission of DDR programs has been underlined. Finally, the recycling of DDR programs must be more attentive to the specificities of the local context to gain relevance and offer hybrid solutions through a community leadership and traditional processes with the involvement of local and ordinary actors and families to consolidate the return to peace. As such, some lessons gleaned from this exceptional case can inform other African contexts.

Future research may be more interested in exploring the relevance of the application of the same DDR programs to Boko Haram ex-associates in the same way as for insurgents involved in the Anglophone crisis in Cameroon. A strong interest must also be given to social, land, and ethnic conflicts that may arise from forced displacement due to the Boko Haram security crisis and to the possible implementation of restorative justice mechanisms in those communities. While the COVID-19 crisis has moved priorities, the sudden death of the Chadian president and its implications in the war against violent extremism in the Lake Chad basin remain of greater concern. The very recent death of the Nigerian faction leader Shekau could result in an increase in returning fighters, so it is essential to better plan and adapt the reintegration policies to local contexts.

34 Jordan Goulet, "La Résilience post Boko Haram : le cas de l'Extrême-Nord camerounais," OMIJ - Observatoire des Mutations Institutionnelles et Juridiques, 2019, https://hal.archives-ouvertes.fr/hal-02070795. 


\section{Suggested further reading}

\section{On deradicalization}

Clubb, Gordon, and Marina Tapley. "Conceptualising de-radicalisation and former combatant re-integration in Nigeria." Third World Quarterly 39, no. 11 (2018): 20532068. https://doi.org/10.1080/01436597.2018.1458303.

Gunaratna, Rohan, and Sabariah M. Hussin. Terrorist Deradicalisation in Global Contexts: Success, Failure and Continuity. Routledge, 2019.

Holmer, Georgia, and Adrian Shtuni. Returning Foreign Fighters and the Reintegration Imperative. Washington, D.C.: United States Institute of Peace, March 2017. https://www.usip.org/sites/default/files/2017-03/sr402-returning-foreign-fighters-and-thereintegration-imperative.pdf

Pettinger, Tom. "De-radicalization and Counter-radicalization: Valuable Tools Combating Violent Extremism, or Harmful Methods of Subjugation?." Journal for Deradicalization 12 (2017): 1-59. https://journals.sfu.ca/jd/index.php/id/article/view/109/91.

\section{On DDR and Public policy in Africa}

Delville, Philipe Lavigne, and Sylvie Ayimpam. "Public Policy and Public Action in Africa, between Practical Norms, Political Dynamics and Outside Influences." Anthropologie \& développement no. 4849 (2018): 7-23. https://doi.org/10.4000/anthropodev.656.

Rhea, Randolph Wallace. A Comparative Study of Ex-Combatant Reintegration in the African Great Lakes Region : Trajectories, Processes, and Paradoxes. Washington, D.C.: World Bank, 2014. https://openknowledge.worldbank.org/handle/10986/23837.

Richards, Joanne. "High Risk or Low Risk: Screening for Violent Extremists in DDR Programmes." International Peacekeeping 25, no. 3 (May 393-373: 2018 ,27. https://doi.org/10.1080/13533312.2018.1440177.

\section{On Boko Haram in Cameroon}

Chétima, Melchisedek. “Comprendre Boko Haram à Partir d'une Perspective Historique, Locale et Régionale." Canadian Journal of African Studies / Revue Canadienne Des Études Africaines 54, no. 2 (April 28, 2020): 1-13. https://doi.org/10.1080/0008396 $\underline{8.2019 .1700814}$.

Mahamat, Adam. "Opprobre, Discours Clivants et Sociolectes induits par Boko Haram au Cameroun." Canadian Journal of African Studies 54, no. 2 (2020): 281-297. https://doi.org/10.1080/00083968.2019.1700812.

Pemboura, Aicha. "The Use of Vigilance Committees in Cameroon: From the Operational Effectiveness to Necessity of Thinking the Post-War." SSRG International Journal of Humanities and Social Science 6, no. 6 (2019): 26-34. https://doi. org/10.14445/23942703/ijhss-v6i6p104.

Seignobos, Christian, and Abdourhaman Nassourou. "Religions." In Atlas de La Province Extrême-Nord Cameroun, edited by Olivier lyébi-Mandjek, 145-50. Atlas et Cartes. Marseille: IRD Éditions, 2017. http://books.openedition.org/irdeditions/11596.

Thurston, Alexander. Boko Haram: The History of an African Jihadist Movement. Princeton: Princeton University Press, 2017. https://muse.jhu.edu/book/64667. 


\section{Sources}

Abatan, Jeannine Ella, and Boubacar Sangaré. "Katiba Macina and Boko Haram: including women to what end?." Institut d'Études de Sécurité, Mars 2021. https://issafrica.org/research/west-africa-report/ katiba-macina-and-boko-haram-including-women-to-what-end.

Altier, Mary Beth. Violent Extremist Disengagement and Reintegration: Lessons from Over 30 Years of DDR. Washington, D.C.: RESOLVE Network, 2021. https://doi.org/10.37805/vedr2021.1.

Ashukem, Jean-Claude N. "To Give a Dog a Bad Name to Kill It - Cameroon's Anti-Terrorism Law as a Strategic Framework for Human Rights' Violations." Journal of Contemporary African Studies 39, no. 1 (January 2, 2021): 119-34. https://doi.org/10. 1080/02589001.2020.1839633.

Barkindo, Atta, and Shane Bryans. "De-Radicalising Prisoners in Nigeria: developing a basic prison based de-radicalisation programme." Journal for Deradicalization 7 (2016): 1-25. https://journals.sfu.ca/id/index.php/id/article/view/56/47.

Bilounga, Stève Thiery. "L'Etat camerounais à la croisée des chemins de l'Etat de droit et de l'Etat de police (A propos de la loi du 23 décembre 2014 portant répression des actes de terrorisme)." Droit en Afrique 19, no. 2 (2016): 139-161. https://doi. org/10.5771/2363-6270-2016-2-139.

Coulon, Jocelyn, and Damien Larramendy. Consolidation de la paix et fragilité étatique : l'ONU en République centrafricaine. Montréal : Les Presses de l’Université de Montréal, 2015.

Demobilisation Interagency Working Group on Disarmament, and Reintegration, "Module 2.10: The UN Approach to DDR." Integrated DDR Standards. https://www.unddr.org/modules/IDDRS-2.10-The-UN\%20Approach-to-DDR.pdf.

Fonteh, Akum, Hoinathy Remadji, and Samuel Malik. "Managing the Journey out of Violent Extremism in the Lake Chad Basin." ISS Africa, March 30, 2021. https://issafrica.org/research/west-africa-report/ managing-the-journey-out-of-violent-extremism-in-the-lake-chad-basin.

Goulet, Jordan. "La Résilience post Boko Haram : le cas de l'Extrême-Nord camerounais." OMIJ - Observatoire des Mutations Institutionnelles et Juridiques, 2019. https://hal.archives-ouvertes.fr/hal-02070795.

Herzog-Evans, Martine, and Massil Benbouriche. Evidence-based work with violent extremists: International implications of French terrorist attacks and responses. Lexington Books, 2019.

International Crisis Group. Cameroun: faire face à Boko Haram. 2016. https://www.crisisgroup.org/fr/africa/central-africa/ cameroon/cameroon-confronting-boko-haram.

Issa, Saïbou, and Nadine Machikou. "Reintegrating Former Boko Haram Associates. Perspectives from the Far North." Global Center on Cooperative security, 2019. https://www.globalcenter.org/wp-content/uploads/2019/02/GCCS-PB-ReintegratingFormer-Boko-Haram-Associates-2019.pdf

Issa, Saïbou. Les «coupeurs de route». Histoire du banditisme rural et transfrontalier dans le bassin du lac Tchad. Paris: Karthala, 2010.

Mardsen, Sarah. Reintegrating Extremists: Deradicalisation and Desistance. Palgrave Macmillan, 2016.

Mback, Charles Nach. "La Chefferie traditionnelle au Cameroun: ambiguïtés Juridiques et dérives politiques." Africa Development / Afrique et Développement 25, no. 3/4 (2000): 77-118. https://www.jstor.org/stable/43658045.

Ministry of Justice Cameroon. Rapport sur l'état des Droits de l'Homme au Cameroun. 2018. https://www.spm.gov.cm/site/sites/ default/files/Rapport\%20Minjustice\%202017\%20francais 0.pdf. 
Pout, Christian, Bana Barka, and Edouard Yogo. Boko Haram Au Cameroun : Quelles Nouvelles Dynamiques ? Paris: Du Cygne, 2019.

Richards, Joanne. "High Risk or Low Risk: Screening for Violent Extremists in DDR Programmes." International Peacekeeping 25 no. 3 (May 27, 2018): 373-93. https://doi.org/10.1080/13533312.2018.1440177.

Zelao, Alawadi. "Boko Haram, identités et déconstruction des frontières nationales en Afrique sahélienne." In "Les actes du Colloque « Boko Haram au sahel camerounais. Trajectoires identitaires, expansion territoriale, instrumentalisations et réponses politiques." Revue Béninoise de Science Politique (2017). 


\section{About the Note}

Author: Lydie C. Belporo

Lydie C. Belporo works currently as Research Associate to coordination and study of the project led with the Organisation Internationale de la Francophonie and the UNESCO Chair in the Prevention of Radicalization and Violent Extremism in Canada, Africa and Europe. Lydie is a doctoral candidate at the School of Criminology of the Université de Montréal and a 2021 Pierre Elliott Trudeau Foundation Scholar. Her research interests focus on the governance of extremist violence in sub-Saharan Africa.

The views expressed in this publication are those of the authors. They do not necessarily reflect the views of the RESOLVE Network, the U.S. Institute of Peace, or any entity of the U.S. government.

RESOLVE NETWORK

better research.informed practice.improved policy on violent extremism.

www.resolvenet.org

y 9 in.

United STates

Institute of Peace

Making Peace Possible 